\title{
Examination of Mutations in the HBsAg and Polymerase Genes Induced by Pegylated Interferon Alpha and Oral Antivirals Used in the Treatment of Chronic Hepatitis $B$
}

\author{
Kronik Hepatit B Tedavisinde Kullanılan Pegile İnterferon Alfa ve Oral Antivirallerin \\ HBsAg Geni ve Polimeraz Geni Üzerinde Yaptığı Mutasyonların Araștırılması
}

\author{
(1) Elif Sargın Altunok1, (1) Sila Akhan², (1) Murat Sayan3,4 \\ ${ }^{1}$ Gaziosmanpaşa Training and Research Hospital, Clinic of Infectious Diseases and Clinical Microbiology, Gaziosmanpaşa, Turkey \\ 2Kocaeli University Faculty of Medicine, Department of Infectious Diseases and Clinical Microbiology, Kocaeli, Turkey \\ ${ }^{3}$ Kocaeli University Faculty of Medicine, Clinical Laboratory, Kocaeli, Turkey \\ ${ }^{4}$ Near East University, Research Center of Experimental Health Sciences, Nicosia, Northern Cyprus
}

\begin{abstract}
Objectives: The Hepatitis B Virus is a virus having high mutation frequency due to having a high replication capacity and not having error correction capability in reverse transcription.lt is aimed to examine the mutations created by the oral antivirals used in $\mathrm{CHB}$ treatment on pol gene and $\mathrm{S}$ gene, to determine the clinical and epidemiological significance of these mutations, and to specify the development of drug resistance in long terms and the results it may cause. Secondly, it is aimed to determine whether the quantitative HBsAg titers are early markers for detecting drug resistance or not. Materials and Methods: Correlation analyses were performed with monitoring qHBsAg levels and $\mathrm{HBsAg}(\mathrm{S} / \mathrm{Co})$ and HBV-DNA levels of the patients.

Results: It was seen in the correlation analysis, a statistically significant middle level correlation existed between the initial qHBsAg and HBV-DNA levels. It was concluded that the efficiency of qHBsAg levels on making diagnosis is at a good degree to distinguish inactive $\mathrm{HBsAg}$ carriers and $\mathrm{HBeAg}$ negative $\mathrm{CHB}$ patients, and the cutoff value was determined as $2188 \mathrm{IU} / \mathrm{mL}$. Conclusions: In order to understand the usability of HBsAg titres as a marker in early diagnosis of these mutations more comprehensive studies are required.

Keywords: Chronic hepatitis B, quantitative HBsAg, mutatition, nucleos(t)ide analogs, polymerase gene
\end{abstract}

ÖZ

Amaç: Hepatit B Virusu (HBV), yüksek replikasyon kapasitesinin olması ve ters transkripsiyon işleminde hata düzeltme yeteneğinin olmaması nedeniyle, yüksek mutasyon sıklı̆ına sahip bir virustur. Bu çalışmada KHB tedavisinde kullanılan oral antivirallerin pol geni ve $\mathrm{S}$ geni üzerinde yaptığı mutasyonların araştıııması ve bu mutasyonların klinik ve epidemiyolojik öneminin saptanması, uzun dönemde ilaç direnci gelişiminin ve bunun yol açacağı sonuçların belirlenmesi amaçlanmıştır. Ikincil olarak, kantitatif $\mathrm{HBsAg}(\mathrm{qHBsAg})$ titrelerinin ilaç direncini belirlemede erken bir marker olup olmadığının saptanması amaçlanmıştır.

Gereç ve Yöntemler: Hastaların qHBsAg düzeyleri ile HBsAg (S/ Co) ve HBV-DNA düzeyleri takip edilerek korelasyon analizleri yapıldı. Bulgular: Tedavi alan hastaların tamamı ele alınarak yapılan korelasyon analizlerinde başlangıç qHBsAg ve HBV-DNA seviyeleri arasında istatistiksel olarak anlamlı orta düzeyde bir korelasyon olduğu görüldü. Inaktif $\mathrm{HBsAg}$ taşıyıcıları ile $\mathrm{HBeAg}$ negatif $\mathrm{KHB}$ hastalarını ayırmada qHBsAg düzeylerinin tanı koymadaki etkinliğinin iyi derecede olduğu sonucuna varıldı, cut off değeri ise $2188 \mathrm{IU} / \mathrm{mL}$ olarak belirlendi.

Sonuç: $\mathrm{Bu}$ mutasyonların erken tanısında HBsAg titrelerinin bir belirteç olarak kullanılabilirliğini anlamak için daha kapsamlı çalıșmalara intiyaç vardır.

Anahtar Kelimeler: Kronik hepatit B, kantitatif HBsAg, mutasyon, nükleoz(t)ide analogları, polimeraz geni

Sargın Altunok E, Akhan S, Sayan M. Examination of Mutations in the HBsAg and Polymerase Genes Induced by Pegylated Interferon Alpha and Oral Antivirals Used in the Treatment of Chronic Hepatitis B. Viral Hepat J. 2020;26:141-150.

Address for Correspondence: Elif Sargın Altunok MD, Gaziosmanpaşa Training and Research Hospital, Clinic of Infectious Diseases and Clinical Microbiology, Gaziosmanpaşa, Turkey Phone: +90 5308200244 E-mail: ifsargin@hotmail.com ORCID ID: orcid.org/0000-0002-3244-3768 Received: 08.05.2020 Accepted: 17.09.2020

(ㄷ) Copyright 2020 by Viral Hepatitis Society / Viral Hepatitis Journal published by Galenos Publishing House. 


\section{Introduction}

Despite recent developments in chronic hepatitis B (CHB) treatment, complete eradication of this disease does not seem possible due to the persistence of covalently closed circular DNA (cccDNA) in the nucleus of infected hepatocytes. The primary goal of treatment is the effective repression of hepatitis $B$ virus (HBV)DNA, and if possible, hepatitis B surface antigen (HBsAg) loss and seroconversion, and prevention of complications such as cirrhosis and hepatocellular carcinoma (HCC). Today, interferons (IFN) and nucleoside/nucleotide analogues (NA) are used for the treatment of $\mathrm{CHB}$. IFNs are immunomodulating drugs, which have specific expiration dates, and do not facilitate the development of resistance. NA should be used for at least 1 year to effectively repress HBVDNA. The most significant problem associated with NA treatment is the development of drug resistance and cross-resistance in the long term $(1,2)$. Telbivudine (LdT) is a L-nucleoside analogue with more potent antiviral activity against HBV than Lamivudine (LAM). However, 2-5\% of the patients develop resistance after 1 year of treatment (3). Entecavir (ETV) and tenofovir (TDF) are oral antiviral NA agents that exhibit potent viral suppressive effects and lower resistance rates due to their high genetic barriers (1)

Currently, HBV-DNA level determination, an expensive method requiring experience, is used to make the decision whether to begin antiviral therapy or not, to determine the follow-up response to the treatment, and to determine if there is resistance to the antiviral. Recent studies suggest that predictions about the prognosis of the disease can be made through the use of serum HBsAg quantification (qHBsAg), which is a less costly method. There is a relationship between the HBsAg quantitative values and clinical stage, fibrosis score, and treatment response of the disease. Since serum HBsAg levels correlate with intrahepatic cccDNA levels, quantification reflects the level of infection. Therefore, qHBsAg can be helpful in differentiating $\mathrm{HBeAg}$ negative patients, who have low HBV-DNA levels, from inactive carriers (4).

Due to its high replication capacity $\left(>10^{12}\right.$ virions/day) and the lack of an ability to correct errors, HBV has a high mutation frequency (5). While NA resistance-associated mutations may occur prior to treatment, mutations responsible for resistance to antiviral agents may also occur during long-term treatment of $\mathrm{CHB}$ with NA $(6,7)$. Additionally, due to the polymerase (pol) and surface (S) genes existing in an overlapping position in the HBV genome, NA drug resistance mutations may lead to amino acid changes in the structure of the HBsAg. In recent years, due to the overlapping of the HBV pol/S genes, the term, Antiviral Drug-Associated Potential Vaccine-Escape Mutant (ADAPVEM), has been utilised $(8,9)$.

The goal of this study was to determine the mutations in the pol and $\mathrm{S}$ genes induced by oral antivirals used in the treatment of $\mathrm{CHB}$, to establish the clinical and epidemiological significance of these mutations, and to track the long-term development of drug resistance and determine its consequences. Secondly, we aimed to determine if quantitative HBsAg titres could be utilised as an early marker of drug resistance.

\section{Materials and Methods}

\section{Patients and Study Design}

The study was conducted between 2009 and 2014. This study was approved by the Kocaeli University Faculty of Medicine Ethics Committee of Clinical Research (approval number: 2009/97, date: June 26.06.2009) and written consent was obtained from each patient. Patients for the study were selected from volunteers that were seen in the Infectious Diseases and Clinical Microbiology polyclinic diagnosed with $\mathrm{CHB}$ infection but had not previously undergone treatment. Before inclusion in the study were all patients gave informed consent. Patients with decompensated cirrhosis, hepatocellular carcinoma, alcoholic hepatitis, autoimmune hepatitis, patients with co-infections, pregnant females, lactating females, and minors under 18 years of age were excluded from the study

Peg-IFN treatment was administered to the first patient group, whereas TDF 245 mg/day, ETV 0.5-1 mg/day, LdT 600 mg/day were used as treatments in the second, third, and fourth patient groups, respectively. A fifth group consisted of only inactive HBsAg carriers who received follow-up treatment. As the treatment response criteria, an HBV-DNA viral load $<2000 \mathrm{IU} / \mathrm{mL}$ in the sixth month was used for Peg-IFN-treated patients, while HBV-DNA viral loads determined in the $12^{\text {th }}$ month were used for NA-treated patients.

Prior to treatment, a liver biopsy was obtained from all patients. Histological activity index (HAl) and degree of fibrosis were reported with the values within the ranges 0-18 and 0-6, respectively, using the Ishak modified Knodell system.

\section{Serum HBsAg Quantification}

For patients in the treatment group, the qHBsAg titres were checked prior to, in the third month, and after the first year of treatment; while the qHBsAg titres of inactive HBsAg carriers were measured once every other year, twice in total. Serum qHBsAg was examined using the Electrochemiluminescence Immunoassay method, using the HBsAg II Quant Kit (Roche Diagnostics, Indianapolis, USA) in the Cobas e601 system. The measurement range of the test was determined to be $0.05-130$ $\mathrm{IU} / \mathrm{mL}$ for undiluted samples and 20-52000 $\mathrm{IU} / \mathrm{mL}$ for 400 -fold diluted samples according to Clinical Laboratory Standards Institute EP17-A requirements.

\section{HBV-DNA Measurements}

HBV-DNA was isolated using the QlAsymphony SP magnetic particle isolation platform (QIAGEN GmbH, Hilden, Germany). HBV-DNA was assayed using the Rotor-GENE platform (QIAGEN $\mathrm{GmbH}$, Hilden, Germany), using the real-time PCR technique with the Artus HBV-DNA RGQ kit.

\section{HBV-DNA Sequencing}

HBV genotype/subgenotype determination was analysed by sequencing all known primary/compensatory NA resistance mutations and mutations of the $S$ gene overlapping with the pol gene (HBsAg protein; amino acids 111-227), HBV pol gene (reverse transcriptase; RT region, amino acids 80-250) (10). For this purpose, HBV-DNA was isolated from serum samples (Anatolia Geneworks, Bosphore $®$ Viral DNA Extraction Spin Kit and Magnesia® 16 Magnetic Bead Extraction System, Istanbul, 
Turkey). For HBV pol gene amplification (742 bp), forward (F:5'-TCGTGGTGGACTTCTCTCAATT-3') and reverse (R:5'CGTTGACAGACTTTCCAATCAAT-3') primers were used. For PCR conditions, the following temperature/time cycle was applied: an initial 10 -minute pre-denaturation at $95^{\circ} \mathrm{C}, 35$ cycles at $95^{\circ} \mathrm{C}$ for 45 seconds, at $60^{\circ} \mathrm{C}$ for 45 seconds and at $72^{\circ} \mathrm{C}$ for 45 seconds. All PCR products were purified with the High Pure PCR Product Purification Kit (Roche Diagnostics, Germany). In the sequencing protocol, the Phire Hot Start DNA polymerase (Finnzymes Oy, Finland) enzyme was used. Sequencing was performed using the BigDye Terminator v3.1 Cycle Sequencing Kit (Amersham Pharmacia Biotech Inc., USA), 36-cm capillary and POP-7 TM polymer (Applied Biosystems Inc., USA), according to the manufacturer's recommendations, in the ABI PRISM 3130 (Applied Biosystems Inc., USA) platform. The PCR protocol used for direct sequencing was 35 cycles at $95^{\circ} \mathrm{C}$ for 20 seconds, at $50^{\circ} \mathrm{C}$ for 25 seconds and finally at $60^{\circ} \mathrm{C}$ for 2 minutes. Electropherograms were obtained using the Vector NTI v5.1 (InforMax, Invitrogen, Life Science Software, USA) software. The resulting sequences were analysed in the Geno2pheno Drug Resistance (Center of Advanced European Studies and Research, Germany) software. The Geno2pheno software compares the unknown nucleic acid sequences in fasta format with the reference sequences in its database. After the comparison, amino acids at positions 80, 84, 85, 91, 169, 173, 180, 181, 184, 191, 194, 202, 204, 214, 215, 233, 236- 238 and 250 of the HBV pol gene RT loop were analysed for primary drug resistance and compensatory mutations (10). Additionally, amino acids at positions 121, 135, 137, 139-149, 151-153, 155-157, 161, 164, 172, 173, 175, 176, 182, 193-196 of the $S$ gene region that overlaps with the HBV RT loop were also analysed for the presence of mutations (11).

Patients in the treatment group had their serum HBV-DNA levels checked prior to, in the third month, and after first year of the treatment, while inactive HBsAg carriers were measured once every other year, twice in total. DNA sequence analysis was performed for all patients and again for the inactive $\mathrm{HBsAg}$ carriers whose HBV-DNA level was $>100 \mathrm{IU} / \mathrm{mL}$. DNA sequence analysis was also performed on serum taken when a breakthrough occurred during the follow-up of NA-treated groups.

\section{Statistical Analyses}

The SPSS (SPSS, Inc., Chicago, IL, version 17.0) software package was used to perform the statistical analysis. Qualitative values were expressed as numbers and percentages. Since the measurable values did not conform to a normal distribution, they were given as median values (25-75 percentiles). For comparison of dependent groups, the Wilcoxon and Friedman tests were used, while Mann-Whitney $U$ and Kruska-Wallis tests were performed for comparisons of independent groups. Nominal values were analysed with chi-squared and Fisher's tests. During the statistical assessment, values of $p<0.05$ were considered to indicate significance. For correlation analysis, Spearman's rho test was used. receiver operating characteristic (ROC) analysis was performed using Medcalc version 13.0.6.0. With regard to the correlation coefficients; ranges of $0.70-1.00$; $0.70-0.30$; and 0.30-0 were respectively interpreted as high correlation, moderate correlation, and low correlation, and were accepted as significant at $p<0.01$.

\section{Results}

Fifty-five active CHB-diagnosed but untreated patients and 39 inactive HBsAg carriers, 94 patients in total, were enrolled in our study. Four groups of active CHB-diagnosed patients, containing $15,17,15$, and 8 members, were treated with peg-IFN, TDF, ETV, and LdT, respectively. Thirty-nine patients, who were inactive HBsAg carriers, constituted the control group. Fifty-six of the patients involved in the study were male, while the remaining 38 were female.

Demographic characteristics of the groups, the initial laboratory conditions, HBV-DNA levels, qHBsAg titres, and the histopathological liver characteristics are shown in Table 1. When the initial and first year aspartate aminotransferase (AST), alanine aminotransferase $(A L T), q H B s A g$, and HBV-DNA levels of active CHB-diagnosed patients $(n=55)$ were compared with those of the control group $(n=39)$, a statistically significant difference was observed. In the first year, the treatment group showed no reduction in HBsAg $(\mathrm{S} / \mathrm{CO})$ levels in response to the treatment; however, AST, ALT, qHBsAg, and HBV-DNA levels decreased (Table 2).

In the histopathological examination of 53 active $\mathrm{CHB}$ patients that underwent liver biopsy, 24 patients (45.3\%) had a $\mathrm{HAl} \geq 6$, while 29 patients $(54.7 \%)$ had a score $<6$. Due to cirrhosisassociated thrombocytopenia, a liver biopsy could not be taken from two patients, who were treated with ETV (Table 3).

Thirty-four of the fifty-three active CHB patients from whom a liver biopsy was taken were $\mathrm{HBeAg-negative,} \mathrm{and} 19$ patients were $\mathrm{HBeAg}$-positive. The HBeAg-negative patients were compared to fibrosis scores. The ALT, HBsAg (S/Co), qHBsAg, HBeAg (S/Co), and HBV-DNA viral load values exhibited a significant difference at the beginning of treatment, but not at 12 weeks or after the first year of treatment (Table 4). Regarding the biopsy results of the 19 HBeAg-positive patients, 13 had a fibrosis score less than four, while 6 patients had a fibrosis score equal to or greater than four. The initial ALT values of the group with a fibrosis score equal to or greater than four were significantly higher than those of the group with a fibrosis score of less than four. The qHBsAg level of the group with a fibrosis score less than four was significantly higher at all three time points (Table 5).

The health status of the patients undergoing treatment was evaluated, and their levels of ALT, qHBsAg, HBsAg (S/Co), HBeAg (S/Co), and HBV-DNA viral loads prior to and after 1 year of treatment were compared. Since one of the patients receiving peg-IFN did not respond to the treatment, this patient was omitted from the first year data analysis. Following 1 year of treatment, a statistically significant decrease was observed in ALT, qHBsAg, and HBV-DNA viral load (Table 6).

In the current study, when the patients were grouped according to the phase of $\mathrm{CHB}$ infection, the median $\mathrm{qHBsAg}$ values were $25.405 \mathrm{IU} / \mathrm{mL}$ in HBeAg-positive patients $(n=20), 964.6 \mathrm{IU} / \mathrm{mL}$ in inactive HBsAg carriers $(n=39)$, and $4,797 \mathrm{lU} / \mathrm{mL}$ in $\mathrm{HBeAg}$ negative patients. During the course of treatment, while the ALT, qHBsAg, and HBV-DNA viral load levels decreased in both HBeAgpositive and $\mathrm{HBeAg}$-negative patients in the first year, no decrease in $\mathrm{HBsAg}(\mathrm{S} / \mathrm{Co})$ levels was detected in both groups in response to the treatment (Table 7). 


\begin{tabular}{|c|c|c|c|c|c|c|}
\hline & Peg-IFN & \multirow{2}{*}{$\begin{array}{l}\text { TDF } \\
\text { Median } \\
\text { (min-max) }\end{array}$} & \multirow{2}{*}{$\begin{array}{l}\text { ETV } \\
\text { Median } \\
\text { (min-max) }\end{array}$} & \multirow{2}{*}{$\begin{array}{l}\text { LdT } \\
\text { Median } \\
\text { (min-max) }\end{array}$} & \multirow{2}{*}{$\begin{array}{l}\text { Control group } \\
\text { Median } \\
\text { (min-max) }\end{array}$} & \multirow[t]{2}{*}{$\mathbf{p}^{*}$} \\
\hline & $\begin{array}{l}\text { Median } \\
\text { (min-max) }\end{array}$ & & & & & \\
\hline Age & $36(18-70)$ & $33(24-74)$ & $36(22-55)$ & $34.5(18-68)$ & $40(21-70)$ & 0.392 \\
\hline $\mathrm{HAl}$ & $5(2-7)$ & $6(4-16)$ & $6(2-12)$ & $4.5(4-9)$ & . & 0.038 \\
\hline Fibrosis score & $3(2-4)$ & $4(1-6)$ & $4(2-5)$ & $3(2-4)$ & . & 0.148 \\
\hline AST, U/L & $67(26-126)$ & $53(17-130)$ & $40(17-218)$ & $27.5(16-113)$ & $22(12-78)$ & 0.000 \\
\hline $\mathrm{ALT}, \mathrm{U} / \mathrm{L}$ & $125(37-284)$ & $82(21-248)$ & $70(17-815)$ & $45(19-317)$ & $20(13-108)$ & 0.000 \\
\hline Albumin, g/dL & $4.1(3.8-4.6)$ & $4.3(3.5-4.9)$ & $4.1(3.2-4.5)$ & $4.1(3.8-4.7)$ & $4.4(3.1-5.1)$ & 0.006 \\
\hline Globulin, g/dL & $3.6(2.5-4.3)$ & $3.1(2.5-4.7)$ & $3.1(2.1-3.9)$ & $3.25(2.8-4.1)$ & $2.9(2.1-4.3)$ & 0.054 \\
\hline PTT & $13.9(12.6-14.9)$ & $13.6(12.5-15.9)$ & $13.4(12.1-16)$ & $12.7(12.3-13.3)$ & $13(11.9-14.3)$ & 0.000 \\
\hline INR & $1.1(1-1.2)$ & $1.1(0.9-1.3)$ & $1(0.9-1.3)$ & $0.95(0.9-1)$ & $1(0.9-1.1)$ & 0.000 \\
\hline Platelet, $\times 10^{3} / \mu \mathrm{L}$ & $206(114-333)$ & $207(106-271)$ & $164(58.1-268)$ & $226.5(179-327)$ & $262(153-357)$ & 0.000 \\
\hline $\mathrm{HBsAg}$ (S/Co) & $1843(335.5-5057)$ & $2514(270-6227)$ & $3202(192.1-4351)$ & $3673(1273-6125)$ & 3827 (12.9-6869) & 0.125 \\
\hline qHBsAg (IU/mL) & $9599(213.4-52000)$ & $9776(1781-33406)$ & 5235 (2439-10294) & $5002.5(455.3-33562)$ & $964.6(0.05-19994)$ & 0.000 \\
\hline $\mathrm{HBeAg}$ (S/Co) & $0.341(0.076-1384)$ & $160.6(0.069-1667)$ & $0.383(0.076-2032.9)$ & $0.3565(0.146-140,9)$ & $0.381(0.226-0.533)$ & 0.441 \\
\hline $\begin{array}{l}\mathrm{HBV}-\mathrm{DNA} \times 10^{3} \mathrm{IU} / \\
\mathrm{mL}\end{array}$ & $154(7.64-149000)$ & $\begin{array}{l}11300(0.195- \\
178000)\end{array}$ & $4260(2.37-484000)$ & $30.15(5.61-10500)$ & $0.068(0-1.21)$ & 0.000 \\
\hline \multicolumn{7}{|c|}{$\begin{array}{l}\text { *Kruskal Wallis test. } \\
\text { HAI: Histologic activity index, ALT: Alanine aminotransferase, AST: Aspartate aminotransferase, PTT: Prothrombin tim, INR: International normalized ratio, HBV } \\
\text { Hepatitis B virus, HBsAg: Hepatitis B surface antigen, GHBsAg: Quantitative hepatitis B surface antigen, HBeAg: Hepatitis B e antigen, HBV-DNA: Hepatitis B virus } \\
\text { deoxyribonucleic acid, peg-IFN: Pegylated interferon, TDF: Tenofovir, ETV: Entecavir, LdT: Telbivudine, min: Minimum, max: Maximum }\end{array}$} \\
\hline
\end{tabular}

Table 2. Baseline and first year characteristics of the patients.

\begin{tabular}{|l|l|l|l|}
\hline & Treatment group ( $\mathbf{n = 5 5 )}$ & Control group ( $\mathbf{n = 3 9 )}$ & \\
\cline { 2 - 4 } & Median (25-75\% persentil) & Median (25-75\% persentil) & $\mathbf{p}^{*}$ \\
\hline Baseline AST & $46(32-74)$ & $22(18-25)$ & 0.000 \\
\hline Baseline ALT & $80(52-137)$ & $20(16-33)$ & 0.000 \\
\hline Baseline HBsAg (S/CO) & $2923(1671-4070)$ & $3827(2290-5032)$ & 0.035 \\
\hline Baseline qHBsAg & $5882(3232-21298)$ & $964.6(143.2-3092)$ & 0.000 \\
\hline Baseline HBV-DNA & $346000(18800-33200000)$ & $68(30-425)$ & 0.000 \\
\hline $1^{\text {st }}$ year AST & $24(20-32)$ & $20(15-24)$ & 0.002 \\
\hline $1^{\text {st }}$ year ALT & $27.5(23-36)$ & $21(15-31)$ & 0.006 \\
\hline $1^{\text {st }}$ year HBsAg (S/CO) & $3257(1652-4405)$ & $3651(2150-4454)$ & 0.503 \\
\hline $1^{\text {st }}$ year qHBsAg & $5487(2226-16445)$ & 0.000 \\
\hline $1^{\text {st }}$ year HBV-DNA & $0(0-42)$ & $835.1(174.9-2975)$ & 0.002 \\
\hline $\begin{array}{l}{ }^{*} \text { Mann-Whitney U test. } \\
\text { ALT: Alanine aminotransferase, AST: Aspartate aminotransferase, HBsAg: Hepatitis B surface antigen, qHBsAg: Quantitative hepatitis B surface antigen, HBV-DNA: } \\
\text { Hepatitis B virus deoxyribonucleic acid }\end{array}$ & $44(0-276)$ & \\
\hline
\end{tabular}

Table 3. Comparison of liver histopathological characteristics of patients in the treatment group.

\begin{tabular}{|l|l|l|l|l|}
\hline & Fibrosis <4 $\mathbf{n}(\%)$ & Fibrosis $\geq \mathbf{4} \mathbf{n}(\%)$ & HAI <6 n (\%) & HAI $\geq 6$ n (\%) \\
\hline Peg-IFN $(n=15)$ & $11(73.3 \%)$ & $4(26.7 \%)$ & $11(73.3 \%)$ & $4(26.7 \%)$ \\
\hline TDF $(n=17)$ & $5(29.4 \%)$ & $12(70.6 \%)$ & $6(35.3 \%)$ & $11(64.7 \%)$ \\
\hline ETV $(n=13)$ & $6(46.2 \%)$ & $7(53.8 \%)$ & $6(46.2 \%)$ & $7(53.8 \%)$ \\
\hline LdT $(n=8)$ & $7(87.5 \%)$ & $1(12.5 \%)$ & $6(75 \%)$ & $2(25 \%)$ \\
\hline Total $(n=53)$ & $29(54.7 \%)$ & $29(54.7 \%)$ & $24(45.3 \%)$ \\
\hline HAI: Histologic activity index, peg-IFN: Pegylated interferon, TDF: Tenofovir, ETV: Entecavir, LdT: Telbivudine & \\
\hline
\end{tabular}


The diagnostic efficacy of serum qHBsAg levels to differentiate between inactive HBsAg carriers and $\mathrm{CHB}$ patients was tested by $\mathrm{ROC}$ analysis. The area under curve (AUC) was 0.833 (good), sensitivity $80 \%$, specificity $76.92 \%$ and $p<0.0001$. According to this analysis, the cut-off value for qHBsAg was $3.092 \mathrm{IU} / \mathrm{mL}$ (Figure 1).

The diagnostic efficacy of serum qHBsAg levels for differentiating between inactive $\mathrm{HBsAg}$ carriers and $\mathrm{HBeAg}$ negative $\mathrm{CHB}$ patients was tested by ROC analysis. The AUC was
0.733 (good), sensitivity $80 \%$, specificity $69.2 \%$ and $p<0.0001$ According to this analysis, the cut-off value for qHBsAg was 2.188 $\mathrm{IU} / \mathrm{mL}$ (Figure 2).

\section{Results of Correlation Analyses}

In the correlation analyses of pre-treatment values, a statistically significant negative correlation ( $r=-0.754 /-0.590 ; p=0.000$ ) was determined between HBsAg (S/Co) and both the qHBsAg and HBV-DNA values of treated patients $(n=55)$. Between the initial

Table 4. Comparing baseline, $12^{\text {th }}$ week and first year results of HBeAg negative patients, who are treated, in accordance with fibrosis position

\begin{tabular}{|c|c|c|c|}
\hline & Fibrosis $<4(n=16)$ & Fibrosis $>4(n=18)$ & \\
\hline & Median $(25-75 \%$ persentil) & Median $(25-75 \%$ persentil) & $p^{*}$ \\
\hline Baseline ALT & $85(40-148.5)$ & $86(37-137)$ & 0.959 \\
\hline Baseline HBsAg (S/Co) & 3001 (1897-4652) & 3633 (3202-4565) & 0.384 \\
\hline Baseline qHBsAg $(I \mathrm{U} / \mathrm{mL})$ & $5217(1990.5-16190.5)$ & $4252(2439-5567)$ & 0.443 \\
\hline Baseline $\mathrm{HBeAg}(\mathrm{S} / \mathrm{Co})$ & $0.28(0.095-0.42)$ & $0,31(0,12-0,4)$ & 0.958 \\
\hline Baseline HBV-DNA, $\times 10^{3} \mathrm{IU} / \mathrm{mL}$ & $30.15(15.05-129.6)$ & $74,85(8,9-473)$ & 0.646 \\
\hline $12^{\text {th }}$ week ALT & $35.5(21-46)$ & $35(23-56)$ & 0.878 \\
\hline $12^{\text {th }}$ week HBsAg (S/Co) & $3728(2728.5-4540.5)$ & $3434(2103-4082)$ & 0.33 \\
\hline $12^{\text {th }}$ week qHBsAg $(I U / m L)$ & $4907.5(1715-13627.5)$ & $3818(1870-4407)$ & 0.164 \\
\hline $12^{\text {th }}$ week $\mathrm{HBeAg}(\mathrm{S} / \mathrm{Co})$ & $0.34(0.3-0.4)$ & $0.32(0.27-0.34)$ & 0.237 \\
\hline $12^{\text {th }}$ week HBV-DNA & $30(0-40.5)$ & $0(0-30)$ & 0.365 \\
\hline $1^{\text {st }}$ year ALT & $31(25.5-51)$ & $25(20-34)$ & 0.109 \\
\hline $1^{\text {st }}$ year $\mathrm{HBsAg}(\mathrm{S} / \mathrm{Co})$ & 3359 (2196-4260) & 4391.5 (3682-4857) & 0.109 \\
\hline $1^{\text {st }}$ year qHBsAg $(\mathrm{IU} / \mathrm{mL})$ & $4953.5(635.75-10113)$ & 3124 (1511-5210) & 0.528 \\
\hline $1^{\text {st }}$ year $\mathrm{HBeAg}(\mathrm{S} / \mathrm{Co})$ & $0.37(0.28-0.4)$ & $0.35(0.28-0.43)$ & 1 \\
\hline $1^{\text {st }}$ year HBV-DNA & $0(0-15)$ & $0(0-0)$ & 0.33 \\
\hline
\end{tabular}

Table 5. Comparing baseline, $12^{\text {th }}$ week and first year results of $\mathrm{HBeAg}$-positive patients, who are treated, in accordance with fibrosis position

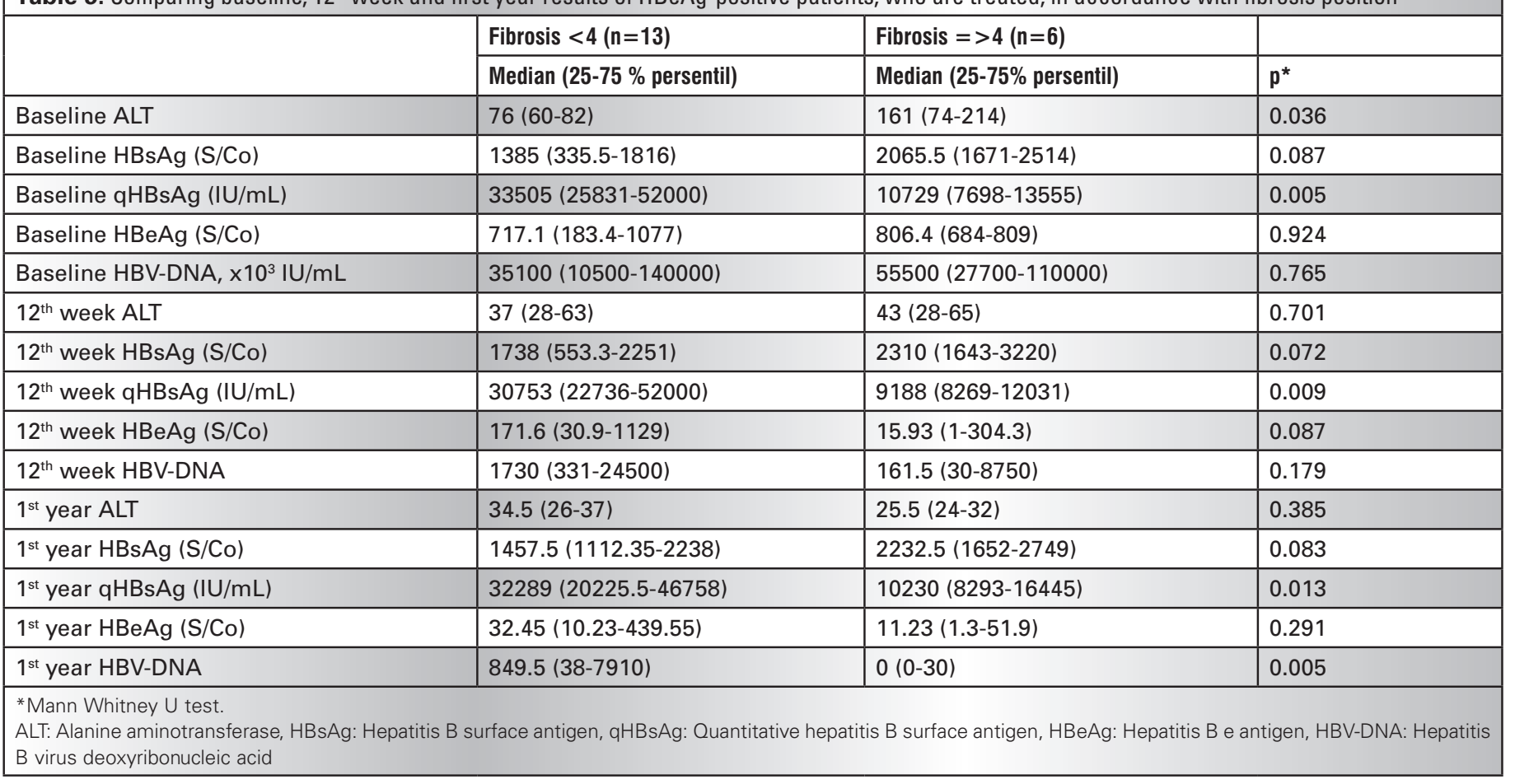




\begin{tabular}{|c|c|c|c|c|c|}
\hline & $\mathrm{n}$ & Median & $25-75 \%$ persentil & Min-max & $\mathbf{p}^{*}$ \\
\hline Baseline ALT & 55 & 80.00 & $52-137$ & $17-815$ & \multirow{2}{*}{$<0.0001$} \\
\hline $1^{\text {st }}$ year ALT & 54 & 27.50 & 22.75-36 & $11-101$ & \\
\hline HBsAg (S/Co) & 55 & 2923.00 & $1671-4070$ & $192.1-6227$ & \multirow{2}{*}{0.106} \\
\hline $1^{\text {st }}$ year HBsAg (S/Co) & 54 & 3257.00 & $1635-4407$ & $2.7-5463$ & \\
\hline qHBsAg (IU/mL) & 55 & 5882.00 & $3232-21298$ & 213.4-171800 & \multirow{2}{*}{0.004} \\
\hline $1^{\text {st }}$ year qHBsAg (IU/mL) & 54 & 5487.00 & $2136-16860.25$ & $0.08-52000$ & \\
\hline HBV-DNA, x $10^{3} \mathrm{IU} / \mathrm{ml}$ & 55 & 346 & $18.8-33200$ & $0.195-484000$ & \multirow{2}{*}{$<0.0001$} \\
\hline $1^{\text {st }}$ year HBV-DNA & 54 & 0.00 & $0-43$ & $0-56700$ & \\
\hline
\end{tabular}

Table 7. Comparing the chronic hepatitis B infection of patients by their phases

\begin{tabular}{|l|l|l|l|}
\hline & HBeAg-positive patients ( $\mathbf{n}=\mathbf{2 0})$ & Inactive HBsAg carriers (n=39) & HbeAg-negative patients (n=35) \\
\cline { 2 - 4 } & Median (25-75\% persentil) & Median (25-75\% persentil) & Median (25-75\% persentil) \\
\hline Baseline AST & $49.5(32 / 88)$ & $22(18 / 25)$ & $46(32 / 74)$ \\
\hline Baseline ALT & $79(61.5 / 143)$ & $20(16 / 33)$ & $83(37 / 137)$ \\
\hline Baseline HBsAg (S/Co) & $1681.5(840.5 / 2305.5)$ & $3827(2290 / 5032)$ & $3539(2839 / 4565)$ \\
\hline Baseline qHBsAg (IU/MI) & $25405(10071 / 42781)$ & $964.6(143.2 / 3092)$ & $4797(2333 / 7431)$ \\
\hline Baseline HBeAg (S/Co) & $790(183.4 / 11929)$ & $0.381(0.35 / 0.41)$ & $0.2945(0.10 / 0.40)$ \\
\hline Baseline HBV-DNA & 41350000 & $68(30 / 425)$ & $49100(13400 / 251000)$ \\
\hline $1^{\text {st }}$ year AST & $(14100000 / 128000000)$ & $20(15 / 24)$ & $25(21 / 36)$ \\
\hline $1^{\text {st }}$ year ALT & $22(20 / 28)$ & $21(15 / 31)$ & $27(22 / 36)$ \\
\hline $1^{\text {st }}$ year HBsAg (S/Co) & $32(24 / 36)$ & $3651(2150 / 4454)$ & $3979(3088 / 4513)$ \\
\hline $1^{\text {st }}$ year qHBsAg (IU/mL) & $1652(1320 / 2658)$ & $835.1(174 / 2975)$ & $3789(946.8 / 5623)$ \\
\hline $1^{\text {st }}$ year HBeAg (S/Co) & $18970(8293 / 38678)$ & $0.433(0.40 / 0.49)$ & $0.355(0.28 / 0.42)$ \\
\hline $1^{\text {st }}$ year HBV-DNA & $23.06(2.64 / 139.1)$ & $44(0 / 276)$ & $0(0 / 0)$ \\
\hline $\begin{array}{l}\text { ALT: Alanine aminotransferase, AST: Aspartate aminotransferase, HBsAg: Hepatitis B surface antigen, qHBsAg: Quantitative hepatitis B surface antigen, HBeAg: } \\
\text { Hepatitis B e antigen, HBV-DNA: Hepatitis B virus deoxyribonucleic acid }\end{array}$ & & \\
\hline
\end{tabular}

qHBsAg and HBV-DNA values of the treated patients $(n=55)$, a statistically significant moderate correlation ( $r=0.619, p=0.000)$ was detected. When a correlation analysis was performed for the initial HBsAg (S/Co), qHBsAg, and HBV-DNA values of the control group ( $n=39$ ), no statistically significant correlation was determined.

When the treated patients were grouped according to their fibrosis status, a statistically significant negative correlation was observed between the initial HBsAg (S/Co) with both qHBsAg and HBV-DNA values in both groups, one with a fibrosis score $<4(n=29)$ and the other having a fibrosis score $\geq 4(n=24)$ (in the group with a fibrosis score <4: $r=-0.804 /-0.611, p=0.000$; in the group with a fibrosis score $\geq 4$ : $r=-0.533 /-0.553, p=0.007 / 0.005$ ). Between the initial qHBsAg and HBV-DNA values of the group with a fibrosis score $<4$, a statistically significant high correlation $(r=0.759, p=0.000)$ was identified; whereas a statistically significant moderate correlation ( $r=0.661, p=0.000$ ) was observed between the initial qHBsAg and HBV-DNA values of the group with a fibrosis score $\geq 4$.
When the treated patients were divided into the peg-IFN treated group $(n=15)$, and the NA-treated group $(n=40)$, and analysed in terms of correlations of initial values; no statistically significant correlation was observed between HBsAg (S/Co), qHBsAg, and HBV-DNA values of the peg-IFN treated group. However, in the NA-treated group, a statistically significant negative correlation $(r=-$ $0.886 /-0.712, p=0.000$ ) was identified between HBsAg (S/Co) with both qHBsAg and HBV-DNA.

After the treated patients were grouped into $\mathrm{HBeAg}$-positive $(n=20)$ and $\mathrm{HBeAg}(n=35)$ negative groups, no correlation was detected between the initial qHBsAg and HBV-DNA values of the groups. However, following the first year of treatment a statistically significant high correlation ( $r=0.736, p=0.000)$ was identified between the $\mathrm{gHBsAg}$ and HBV-DNA values of the HBeAg-positive patient group.

Correlation analyses performed after 1 year of treatment demonstrated a statistically significant negative correlation ( $r=-$ 0.588/-0.432; $\mathrm{p}=0.000 / 0.001$ ) between HBsAg (S/Co) and both 


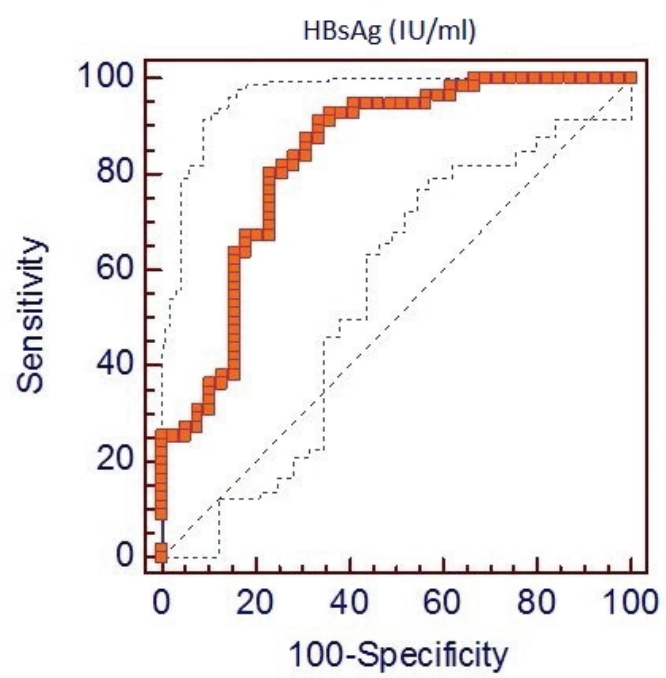

Figure 1. Effectiveness of $\mathrm{qHBsAg}$ in establishing diagnosis in distinguishing between inactive $\mathrm{HBsAg}$ carriers and chronic hepatitis B patients. When tested by ROC analysis AUC: $0.833,80 \%$ sensitivity specificity $76.92 \%$, a cut-off value for HBsAg $3092 \mathrm{IU} / \mathrm{mL}, \mathrm{p}<0.0001$

qHBsAg: Quantitative hepatitis B surface antigen, HBsAg: Hepatitis B surface antigen, ROC: Receiver operating characteristic, AUC: Area under curve

qHBsAg and HBV-DNA in all treated patients. After the first year, a statistically significant moderate correlation $(r=0.512, p=0.000)$ was observed between the qHBsAg and HBV-DNA values of the treated patients. In the first year results of the control group $(n=39)$, while no statistically significant correlation between $\mathrm{HBsAg}(\mathrm{S} / \mathrm{Co})$ and qHBsAg and HBV-DNA values was observed, a statistically significant low correlation $(r=0.418, p=0.008)$ was detected between the qHBsAg and HBV-DNA values.

\section{Treatment Responses}

When a qHBsAg value $<1500 \mathrm{IU} / \mathrm{mL}$ was accepted as the treatment response criterion, the number of patients that responded in the third month was four $(26.7 \%)$ in the peg-IFN group, one in the TDF group (5.9\%), one in the ETV group $(6.7 \%)$, and two in the LdT group (25\%). After the first year of treatment, six patients (42.9\%) in the peg-IFN group responded to the treatment, and one patient from the TDF group (5.9\%), two patients from the ETV group (13.3\%), and two patients from the LdT group (25\%) showed responses.

\section{HBV-DNA Sequencing Analyses}

HBV-DNA sequencing was performed using serum collected prior to treatment from 71 of the total of 94 naive patients in the study. All patients were infected with genotype D. According to the HBV subgenotyping results, 65 of 71 patients were infected with D1, 4 with D2, and 2 patients were infected with D3. The HBV pol gene region was analysed for drug resistance mutations in all patients (Table 8). The HBsAg escape mutations detected are shown in Table 9. In addition, ADAPVEM analysis was performed on the patients that underwent HBV-DNA sequencing analysis. In these patients, two naturally developing ADAPVEM patternsW196*/L/S (treated with peg-IFN) and S193L (treated with LdT)were detected.

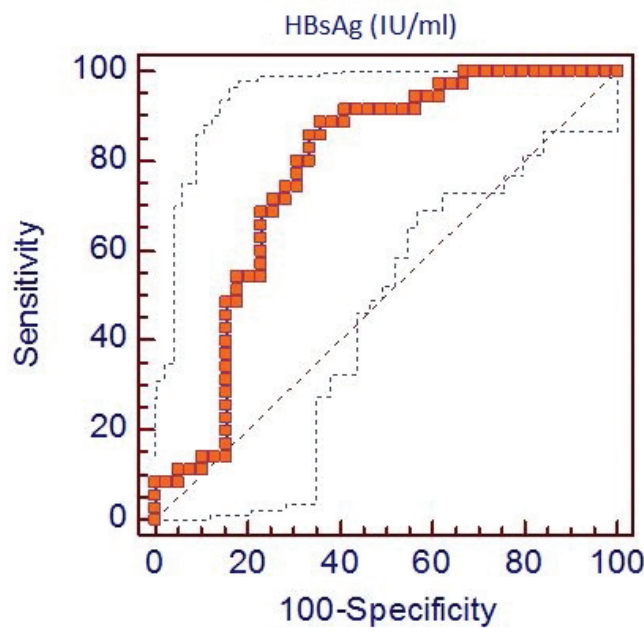

Figure 2: Effectiveness of $\mathrm{qHBsAg}$ in establishing diagnosis in distinguishing between inactive HBsAg carriers and HBeAg-negative chronic hepatitis B patients. When tested by ROC analysis AUC: 0.733 , $80 \%$ sensitivity, $69.2 \%$ specificity, cut-off value for $\mathrm{HBsAg} 2188 \mathrm{IU} / \mathrm{mL}$, $\mathrm{p}<0.0001$

qHBsAg: Quantitative hepatitis B surface antigen, HBsAg: Hepatitis B surface antigen, ROC: Receiver operating characteristic, AUC: Area under curve

In one patient in the peg-IFN-treated group, 1 year after completing 48 weeks of IFN treatment, the development of HBsAg loss was observed. Comparisons of the HBV-DNA sequences prior to and after treatment indicated that an $1110 \mathrm{~L}$ leakage in the immune system mutation occurred in the $\mathrm{S}$ gene.

Following a breakthrough in 3 of the total of 17 TDF-treated patients, HBV-DNA sequencing analysis was performed. Two of these three patients exhibited no mutations in any of the analyses performed (analysis of one patients was performed in the first, and the other in the second, year) either in the pre-treatment period or during the period when the breakthrough developed. When treatment of the patient who experienced breakthrough in the second year of his treatment was continued, it was determined that his viral load became negative and $\mathrm{HBeAg}$ seroconversion developed at the end of the third year. While the third patient from the TDF group also had a breakthrough, a N236T mutation was detected in the D2 subtype and pol gene prior to receiving treatment; however, a L126I mutation was detected in the S gene after the first year, when the breakthrough developed. In another patient from the TDF group, $\mathrm{HBeAg}$ seroconversion developed during the first year of the treatment, although HBV-DNA remained positive.

One of the patients from the ETV group demonstrated no mutations in the pre-treatment analyses, or a response to treatment after the first year, so the treatment was ended. In the second year of treatments in 2 of the 15 ETV-treated patients, loss of $\mathrm{HBeAg}$ was determined, but no mutation was detected in the pre-treatment analyses of both patients.

\section{Discussion}

HBsAg is produced from the integration of the HBV-DNA molecule into the host genome through the use of host enzymes 
or through the translation of transcriptionally active cccDNA molecules. It is thought that serum HBsAg levels are correlated with intrahepatic cccDNA levels, and quantification can be used as a marker of the level of liver cell infection (12). Chan and Wong (13) reported that the relationship between qHBsAg levels with HBVDNA and cccDNA changes depends on the phase of the disease. In the same study, it was reported that there was no correlation in the $\mathrm{HBeAg}$-negative group, while in the $\mathrm{HBeAg}$-positive patient group a positive correlation was observed between HBsAg titre and HBV-DNA and cccDNA levels (13). Lee et al. (14) reported that if the HBsAg level in HBeAg-positive patients was $<3,000 \mathrm{IU} / \mathrm{mL}$ in the third month of treatment, qHBsAg can be accepted as an independent predictive factor for HBV-DNA negativity and $\mathrm{HBeAg}$ seroconversion in the first year of treatment. However, since the HBsAg titre was continuously increasing during treatment in the HBeAg-negative group, it was concluded that the qHBsAg level was not suitable for use in the follow-up of treatment (14). Correlation analyses including all of the patients treated in our study demonstrated a statistically significant moderate correlation between the initial qHBsAg and HBV-DNA levels. However, no significant correlation was observed between the initial qHBsAg and HBV-DNA levels of inactive HBsAg carriers.
Brunetto et al. (15) concluded that qHBsAg level, when considered in combination with the HBV-DNA level, could be used specifically to distinguish the $\mathrm{HBeAg}$-negative $\mathrm{CHB}$ group from the inactive HBsAg-carrier group. When the diagnostic efficacy of serum qHBsAg levels to distinguish inactive HBsAg carriers from $\mathrm{CHB}$ patients was tested using $\mathrm{ROC}$ analysis in our study, the diagnostic efficacy, sensitivity, and specificity of qHBsAg were determined to be good, 80\%, and 76.92\% ( $\mathrm{p}<0.0001)$, respectively. According to this analysis, the cut-off value for qHBsAg was 3,092 IU/mL (Figure 1). Similarly, to distinguish inactive HBsAg carriers from HBeAg-negative CHB patients, the diagnostic efficacy, sensitivity and specificity of serum qHBsAg levels were determined to be good, $80 \%$, and $69.2 \%(p<0.0001)$, respectively. The cut-off value for $\mathrm{qHBsAg}$ was $2,188 \mathrm{IU} / \mathrm{mL}$ according to this analysis (Figure 2).

NA used in $\mathrm{CHB}$ treatment can cause the development of point mutations in the pol gene. When a point mutation occurs, drug resistance can also develop (16). These mutations are mainly divided into two groups: primary drug resistance mutations that cause unresponsiveness to the drugs used and compensatory mutations affecting viral fitness (viral load increasing and replication capacity reparative). In our study, we detected primary drug resistance mutations during the naïve period of two patients: the

\begin{tabular}{|c|c|c|c|}
\hline \multirow{2}{*}{$\begin{array}{l}\text { HBV polymerase gene mutations } \\
\text { character }\end{array}$} & Patients who underwent analysis $(n=71)$ & \multirow[t]{2}{*}{ Clinical significance } & \multirow[t]{2}{*}{ Treatment given } \\
\hline & The pattern of mutation, (n) & & \\
\hline \multirow[b]{2}{*}{ Primary drug resistance mutation } & M204I (1) & LdT and LAM resistance & Peg-IFN \\
\hline & N236T (1) & $\begin{array}{l}\text { ADV resistance, mutations reducing } \\
\text { the susceptibility to TDF }\end{array}$ & TDF \\
\hline Partial drug resistance mutation & M204I (1) & ETV resistance & Peg-IFN \\
\hline \multirow{7}{*}{ Compensatory mutation } & L91I (3) & Associated with LdT & TDF \\
\hline & Q149K (1) & Associated with LAM and ADV & TDF \\
\hline & N139K (1) & - & TDF \\
\hline & V214A (2) & Associated with LAM and ADV & TDF/control group \\
\hline & Q215S (3) & Associated with LAM and ADV & TDF/LdT/control group \\
\hline & $\mathrm{O} 215 \mathrm{H}(1)$ & Associated with LAM and ADV & Control group \\
\hline & N238D (1) & Associated with ADV & Control group \\
\hline
\end{tabular}

\begin{tabular}{|l|l|}
\hline Table 9. Typical HBsAg escaping mutations in HBV S gene in patients who may be subject to HBV-DNA sequence analysis \\
\hline HBV S gene mutation character & Patients who underwent analysis ( $\mathbf{n}=71)$ \\
\cline { 2 - 3 } & The pattern of mutation, (n) \\
\hline HBlg escape & $\begin{array}{l}\text { T123N (1), P142S (1), G145R (1), P120T (1), G119R (2), T126I (1), C124 (1), C139S (1), } \\
\text { K141I (1), Q129H (1), L126I* (1). }\end{array}$ \\
\hline Vaccine escape & $\begin{array}{l}\text { P142S (1), G130R (1), S143L (1), G145R (1), Q129H (1), L109R (1), Q129R (1), T126I (1), } \\
\text { P120T (1), L126I* (1). }\end{array}$ \\
\hline Diagnostic test escape & $\begin{array}{l}\text { R122K (1), T123N (1), P142S (1), G130R (1), M133T (1), S143L (1), G145R (1), P120T (1), } \\
\text { G145L (1), Q129R (1), T131N (2). }\end{array}$ \\
\hline Immune response escape & I110L (1), S132F (1), I110L (1), P120R (1). \\
\hline *Mutation detected in analysis when a breakthrough develops. \\
HBV: Hepatitis B virus, S: Surface, HBlg: Hepatitis B immunoglobulin
\end{tabular}


M204I mutation causing LdT and LAM resistance, and the N236T mutation causing ADV resistance and decreasing sensitivity to TDF (Table 8). When HBV-DNA sequencing analysis was redone in a TDF-treated patient who had a naturally occurring N236T mutation after a breakthrough developed in the first year of treatment, an L126I mutation was detected in the S gene. The detection of a naturally occurring N236T mutation, which reduces susceptibility to TDF, in this D2 subgenotype patient explains the breakthrough that developed in the first year of treatment, and indicates the importance of a pre-treatment mutation analysis.

Some studies have demonstrated that primary drug resistance, which develops in $\mathrm{CHB}$ infection in response to NA treatment, also increases the HCC risk. In one study, it was reported that HCC developed due to SL21*, sW156* and sW172* mutations in 8 of $141 \mathrm{HCC}$ patients with CHB (17) In another prospective study, the cumulative risk of HCC development (30.6\%) in patients displaying primary drug resistance $(n=36)$, among 198 patients that had decompensated cirrhosis, were treated with NA, and followed-up for 2 years, was higher than in patients who developed virological responses (18). In the current study, we did not detect any mutation that increased the risk of progression to HCC.

Due to the circular organisation of the HBV genome, NA used in the treatment of $\mathrm{CHB}$ can lead to the formation of typical HBsAg escape mutations in the S gene. sP120T, sM133I, sS143L, sD144A/E, sG145R, sE164D, sW172* and sW182* are examples of such mutations, which are of clinical and epidemiological significance $(10,19,20)$. Typical HBsAg escape mutations can also lead to a failure to detect HBsAg using diagnostic tests, the protection generated by HBlg, and deficiency of anti-HBs antibodies following vaccination (21). It has been reported that G145R and $\mathrm{P} 120 \mathrm{~T}$, which are examples of hepatitis B vaccine/HBlg escape mutations, can be present in combination with LAM-associated resistance mutations (22). In addition, a sT143* mutation causing HBV vaccine leak in a child with $\mathrm{CHB}$, sM125T and sT127P mutations causing HBsAg escape mutations in the child's family, and a sS143L mutation resulting in escape from an $\mathrm{HBsAg}$ diagnostic test in one patient that was not vaccinated against $\mathrm{HCV}$, have been reported in Turkey $(23,24,25)$. A breakthrough developed in three patients treated with NA in our study, and no mutations were detected in two of these patients. As a result of the analyses performed after a breakthrough developed in one patient at the end of the first year of treatment, a L126I mutation, a hepatitis B vaccine/HBlg leak mutation, was detected (Table 9).

In a wide-ranging study conducted on NA-treated $(n=185)$ patients and patients with treatment-naïve CHB $(n=142)$ in Turkey, 15 HBsAg escape mutations (sY100C, sL109l, sl110V, sS117INST, sP120T, sP127T, sG130R, sS132A, sM133l, sY134N, sC137L, sC137G, sD144E, sG145X and sG145R) were detected. Typical $\mathrm{HBsAg}$ escape mutations were detected in patients with $\mathrm{CHB}$, cumulatively at a ratio of $27 / 327(8.3 \%)$, but no difference in typical HBsAg escape mutation prevalence was observed between the NA-treated and treatment-naivve patients (10). These data suggest that typical HBsAg escape mutations can also develop naturally. In another study conducted in Turkish patients undergoing haemodialysis, it was reported that typical HBsAg escape mutations were detected in 43/94 (46\%) treatment-naive CHB patients. Among these patients, HBlg escape mutations
(sT118A/R，sP120K/Q/T, sT123A，sC124G，sQ129R，sM133L, sY134N, sD144E, sG145E/K/R) were present at an 18/43 (18\%) ratio; HBV vaccine escape mutations (sP120S, sT126l, sM133L, sS143L, sD144E, sG145R, sS193L) at a 15/43 (16\%) ratio; HBsAg diagnostic test escape mutations (sP120S/T, sT131I, sM133T, sS143L) at a 8/43 (8.5\%) ratio; and immune response escape mutations (sY100C/S, sQ101H/R, sP105A/R, sL109R, sl110L, sS114A/, sS117G/N, sG119l/R/N, sP120T, sT123A/D/N, sP127T, sA128V, sG130E/K/R, sT131N, sS132C/P, sY134F, sT140I, sS143T, sD144E, sG145R) at a $31 / 43$ (33\%) (26). As a result of the pretreatment analyses performed in our study, typical HBsAg escape mutations were detected in $17 / 71$ (24\%) of the patients (Table 9). The detected pattern is consistent with previous studies conducted in Turkey $(21,27,28)$. Detection of typical HBsAg escape mutations in $\mathrm{CHB}$ patients that were not treated with NA, despite the differences in the patterns defined, suggests that these mutations can result from both NA-treatment and HBV's natural kinetics.

Due to the circular structure of the HBV genome, the pol gene (encodes reverse transcriptase) and the $\mathrm{S}$ gene (encodes HBsAg protein) are in overlapping positions (20). Overlapping of these genes (pol/S) leads to changes in the region encoding the HBsAg protein because of primer/compensatory drug resistance mutations. This situation leads to the formation of ADAPVEM according to recent findings. Additionally, the overlap of the pol and $\mathrm{S}$ genes can cause problems that can directly affect public health. For example, the formation of escape mutations from anti HBs antibodies in people with HBV vaccine-induced immunity, the formation of HBsAg diagnostic test escape variants, and the formation of HB Ig protection escape variants (19). In a study conducted in $\mathrm{CHB}$ patients in Turkey, six types of ADAPVEM (sE164D, sl195M, sW196L, sW172L, sL175F, s176V) mutation motifs were defined in 10/94 (10.6\%) patients (25). In another comprehensive study conducted in Turkey on CHB patients who were followed-up for approximately 3 years, seven types of ADAPVEM (rtM204V/ sl195M, rtM204l/sW196S, rtM204l/sW196L, rtV173L/sE164D, rtA181T/sW172*, rtA181T/sW172L and rtA181V/sL173F) mutation motifs were detected in 46/442 (24\%) patients. The ADAPVEM ratios of NA-treated and treatment-naive patients were determined to be $44 / 186(24 \%)$, and $2 / 256(0.79 \%)$, respectively, and this difference was statistically significant (29).

In our study, a total of two ADAPVEM mutation motifs (W196*/L/S and S193L) were detected in two patients during the naive period. These findings indicate that NA treatment can cause ADAPVEM mutations, and these mutations can also occur in naïve patients.

\section{Conclusion}

A number of mutations can occur in the pol and $\mathrm{S}$ genes, depending on which oral antivirals are used for the treatment of a $\mathrm{CHB}$ infection. To understand the utility of $\mathrm{HBsAg}$ titres as a marker for the early diagnosis of these mutations, which is of clinical importance, further, more comprehensive studies are required.

Acknowledgements: We thank Doctor Serdar Ay (Sinanpaşa Family Health Center, Istanbul, Turkey) for his statistics support. 


\section{Ethics}

Ethics Committee Approval: This study was approved by the Kocaeli University Faculty of Medicine Ethics Committee of Clinical Research (approval number: 2009/97, date: June 26.06.2009).

Informed Consent: The written consent was obtained from each patient.

Peer-review: Externally peer-reviewed.

\section{Authorship Contributions}

Surgical and Medical Practices: Concept: E.S.A., S.A., Design: E.S.A., S.A., Data Collection or Processing: E.S.A., S.A., M.S. Analysis or Interpretation: E.S.A., S.A., Literature Search: E.S.A., S.A., M.S., Writing: E.S.A., S.A., M.S.

Conflict of Interest: No benefits in any form have been received or will be received from a commercial party related directly or indirectly to the subject of this article.

Financial Disclosure: This study was supported by Kocaeli University, Scientific Research Projects Coordination Unit.

\section{References}

1. Gish RG. Hepatitis B treatment: Current best practices, avoiding resistance. Cleveland Clinic Journal of Medicine. 2009;76:14-19.

2. Kim WR, Benson JT, Hindman AA, C.L. Brosgart, C. FortnerBurton. Decline in need for liver transplantation for end stage liver disease secondary to hepatitis B in the US. 58th Annual Meeting of the American Association fort $\mathrm{h}$ Study of Liver Diseases 2007;12.

3. Liaw YF, Gane E, Leung N, Zeuzem S, Wang Y, Lai CL, Heathcote EJ, Manns M, Bzowej N, Niu J, Han SH, Hwang SG, Cakaloglu Y, Tong MJ, Papatheodoridis G, Chen Y, Brown NA, Albanis E, Galil K, Naoumov NV; GLOBE Study Group. 2-year GLOBE trial results: Telbivudin is superior to lamivudine in patients with chronic hepatitis B. Gastroenterology. 2009;136:486-495.

4. Özkan H. Kronik Hepatit B Enfeksiyonunda Fazlar ve HBsAg kuantifikasyonunun Önemi. Ed: Tabak F, Tosun S. Viral Hepatit 2013. 1. baskı. Istanbul, 2013:295-299.

5. Harrison TJ. Hepatitis B virus: molecular virology and common mutants. Semin Liver Dis. 2006;26:87-96.

6. European Association For The Study Of The Liver. EASL Clinical Practice Guidelines: Management of chronic hepatitis B virus infection. J Hepatol. 2012;57:p.167-185.

7. Shaw T, Bartholomeusz A, Locarnini S. HBV drug resistance: mechanisms, detection, and interpretation. J Hepatol. 2006;44:593-606

8. Clements CJ, Coghlan B, Creati M, Locarnini S, Tedder RS, Torresi J. Global control of hepatitis B virus: does treatment-induced antigenic change affect immunization? Bull World Health Organ. 2010;88:66-73

9. Torresi J. The virological and clinical significans in the overlapping envelope and polymerase genes of hepatitis B virus. J Clin Virol. 2002;25:97-106.

10. Sayan M, Sentürk O, Akhan SÇ, Hülagü $S$, Cekmen MB Monitoring of hepatitis $B$ virus surface antigen escape mutations and concomitantly nucleos(t)ide analog resistance mutations in Turkish patients with chronic hepatitis B. Int J Infect Dis 2010;14:136-141

11. Avellon A, Echevarria JM. Frequency of hepatitis B virus 'a' determinant variants in unselected Spanish chronic carriers. J Med Virol 2006;78:24-36.
12. Hadziyannis E, Hadziyannis SJ. Hepatitis B surface antigen quantification in chronic hepatitis B and its clinical utility, Expert Rev Gastroenterol Hepatol. 2014;8:185-195.

13. Chan HLY, Wong VWS. Serum hepatitis B surface antigen quantitation can reflect hepatitis B virus in the liver and predict treatment response.Clin Gastroenterol Hepatol. 2007:5:14621468.

14. Lee JH, Kim SJ, Ahn SH, Lee J, Park Y, Kim HS. Correlation between quantitative serum HBsAg and HBV DNA test in Korean patients who showed high level of HBsAg. J Clin Pathol. 2010;63:1027-1031.

15. Brunetto MR, Oliveri $F$, Colombatto $P$, Moriconi $F$, Ciccoross P, Coco B, Romagnoli V, Cherubini B, Moscato G, Maina AM, Cavallone D, Bonino F. Hepatitis B surface antigen serum levels help to distinguish active from inactive hepatitis B virus genotype D carriers. Gastroenterology. 2010;139:483-190.

16. Warner N. Locarnini S. Can antiviral therapy for chronic hepatitis B enhance the progression to hepatocellular carcinoma? Antivira Therapy. 2009;14:139-142.

17. Yeh $\mathrm{CT}$, Shen $\mathrm{CH}$, Tai DI, Chu CM, Liaw YF. Identification and characterization of a prevalent hepatitis $\mathrm{B}$ virus $\mathrm{X}$ protein mutant in Taiwanese patients with hepatocellular carcinoma. Oncogene. 2000;19:5213-1520.

18. Li L, Liu W, Chen Yh, Fan CL, Dong PL, Wei FL, Li B, Chen DX, Ding HG. Antiviral drug resistance increases hepatocelluler carsinoma: A prospective decompansated cirrhosis cohort study. World J Gastroenterol. 2013;19:8373-8381.

19. Sheldon J, Rodes B, Zoulim F, Bartholomeusz A, Soriano V. Mutations affecting the replication capasity of the hepatitis B virus. J Viral Hepat. 2006;13:427-434.

20. Locarnini S. Primary resistance, multidrug resistance, and crossresistance pathways in HBV as a consequence of treatment failure. Hepatology International. 2008;2:147-151.

21. Weber B. Genetic variability of the $S$ gene of hepatitis B virus: clinical and diagnostic impact. J Clin Virol. 2005;32:102-112.

22. Bock C, Tillmann H, Torresi J, Klempnauer j, Locarnini S, Manns MP, Trautwein C. The hepatitis B virus polymerase mutants with enhanced replication by lamivudine treatment after liver transplantation. Gastroenterology. 2002;122:264-273.

23. Kutlu T, Soycan LY, Karatayıı, Turkyılmaz AR, Yurdaydın C, Bozdayı $M$. The Şrst identiŞed hepatitis B virus vaccine escape mutation in Turkey. Letter to the Editor. J Clin Virol. 2006;35:201-202.

24. Ozaslan M, Ozaslan E, Barsgan A, Koruk M. Mutations in the S gene region of hepatitis $B$ virus genotype $D$ in Turkish patients. J Genetics. 2007;86:195-201.

25. Sayiner AA, Agca $H$, Sengonul A, Celik A, Akarsu M. A new hepatitis $B$ virus vaccine escape mutation in a renal transplant recipient. J Clin Virol. 2007;38:157-160.

26. Sayan M, Cavdar C, Doğan C. Naturally occuring polimeraz and surface gene variants of hepatitis B virus in Turkish hemodialysis patients with chronic hepatitis B. Jpn J Infect Dis. 2012;65:495501

27. Sayan M, Akhan SÇ, Meriç M. Naturally occuring amino-acid substitutions to nucleos(t)ide analogues in treatment naive Turkish patients with chronic hepatitis B. J Viral Hepat. 2010;17:23-27.

28. Pei F, Ning JY, You JF, Yang JP, Zheng J. YMDD variants of HBV DNA polymerase gene: rapid detection and clinicopathological analysis with long-term lamivudine therapy after liver transplantation. World J Gastroenterol. 2005;11:2714-2719.

29. Sayan M, Akhan SC. Antiviral drug-associated potential vaccineescape HBV mutants in Turkish patients with chronic hepatitis B. Int J Infect Dis. 2011:15:e722-6. 